\title{
H2BC1 Gene
}

National Cancer Institute

\section{Source}

National Cancer Institute. H2BC1 Gene. NCI Thesaurus. Code C162918.

This gene is involved in histone-mediated chromatin remodeling in male germ cells. 